\title{
Stigma and risky behaviors among male clients of sex workers in the UK in 2001
}

Article

Accepted Version

Della Giusta, M., Di Tommaso, M. L. and Jewell, S. (2017) Stigma and risky behaviors among male clients of sex workers in the UK in 2001. Feminist Economics, 23 (3). pp. 23-48. ISSN 1466-4372 doi: https://doi.org/10.1080/13545701.2016.1203453 Available at https://centaur.reading.ac.uk/62259/

It is advisable to refer to the publisher's version if you intend to cite from the work. See Guidance on citing.

To link to this article DOI: http://dx.doi.org/10.1080/13545701.2016.1203453

Publisher: Taylor \& Francis

All outputs in CentAUR are protected by Intellectual Property Rights law, including copyright law. Copyright and IPR is retained by the creators or other copyright holders. Terms and conditions for use of this material are defined in the End User Agreement.

\section{www.reading.ac.uk/centaur}

\section{CentAUR}

Central Archive at the University of Reading 
Reading's research outputs online 


\section{Stigma and Risky Behaviors Among Male Clients of Sex Workers in the UK in 2001}

\section{Introduction}

Sex work is an activity carried out by women, men, and transgender mostly, although not exclusively, to cater for male demand. It has been widely studied in the social sciences along a variety of dimensions including violence, immigration and sex tourism (Susanne Thorbek and Bandana Pattanaik 2002, Jacqueline Sanchez Taylor and Julia O'Connell Davidson., 2010), identity and rights (Joanna Brewis and Stephen Linstead, 2000, Gail Pheterson, 1995), drug abuse, HIV risks and regulatory concerns (Marina Della Giusta and Vanessa Munro, 2008; Jane Scoular, 2010). Many social scientists have also taken a critical approach to the rhetoric around trafficking and slavery (Julia O`Connell Davidson 2014, Ronald Weitzer 2014, 2015a, 2015b, Kamala Kempadoo, Jyoti Sanghera, Bandana Pattanaik 2011, Laura Agustin 2007).

The economic literature has also approached a number of issues related to both selling and buying sex: prices and supply characteristics (Samuel Cameron, Alan Collins and Neill Thew et al 1999; Peter Moffatt and Simon Peters 2001; Lena Edlund and Evelyn Korn 2002; Samuel Cameron, 2002), demand determinants (Samuel Cameron and Alan Collins 2003), health risks and the effect of condom use on sex workers' earnings (Vijayendra Rao, Indrani Gupta, Michael Lokshin and Smarajit Jana 2001; Paul Gertler, Manisha Shah and Stefano Bertozzi 2003), the evolution of paid sex markets and the ways in which urban spaces favor sexual transactions (Alan Collins 2004), the effect of men in transit on the demand for paid sex (Scott 
Cunningham and Todd Kendall, 2011), the connections with trafficking (Maura Laura Di Tommaso, Isilda Shima, Steinar Strøm and Francesca Bettio 2009), the role of asymmetric information and transaction costs in bargaining over price and working conditions (Debra Satz 2010; Neha Hui 2012; Amy Farmer and Andrew Horowitz 2013).

Economic studies focusing on sex workers have engaged with compensation as partly reflecting compensation for social exclusion, risk (violence, disease, arrest, punishment), front loading in wage profile (informal pension scheme or insurance), boredom and physical effort, distaste (potential psychological and physical costs), loss of recreational sex pleasure, and anti-social and inconvenient hours. Economists have discussed prices, risks for both sex workers and clients, the role of taboos, and of agent fees (Cameron, 2002).

More controversially, the wages of sex workers have been described as 'high' for a 'low skill' occupation and explained by the loss of position in the marriage market (Edlund and Korn, 2002). The latter work motivated our earlier papers in which we showed that stigma is fundamentally related to the nature of the transaction between sex workers and clients, and that clients do not simply demand sex (or companionship as recently discussed by Teela Sanders, 2008), but also a form of control and part of the construction of the client identity (Marina Della Giusta, Maria Laura Di Tommaso, and Steinar Strøm 2009a, Coy et al, 2007), and this appears to be true of existing studies of female clients (for recent evidence see Bauer, 2014). Gender is in this sense not the only dimension that matters to the transaction, as the literature discussed in what follows illustrates how race and ethnicity are also used to construct social distance between clients and sex workers and it is in this sense that our model is helpful, given that it does not explicitly state that the client is a male and the sex worker a female, which would obscure the 
vast male sex work market, the significant market for couples buying sexual services and the small but nonetheless relevant 'romance holiday' and escort market for female clients.

Attitudes towards the exchange of paid sex fundamentally shape the dynamics of demand and supply and the resulting markets as they affect regulation, location, prices, and risk for both sex workers and clients, as well as the institutional form of organisation of the trade (brothels, pimps, escort services etc.) and the entry mode (including trafficking). Stigma has always been associated with sex work from Victorian concerns with the evil personality of sex workers to the concern prevalent from the nineteenth century of sex workers as victims (Ine Vanwesenbeeck 2001), and partly associated with sex of a non-reproductive nature which is seen as threatening marriage (Simone de Beauvoir, 1949). More recent debates have focused on objectification of the body and whether the selling the body and the selling of the self are inextricably linked (Caroline Pateman 1983; Martha Nussbaum 1999) and feminist debates on the issue have been heated with strong divisions between pro-sex work and abolitionist camps.

Although there are papers in the literature addressing the effect of stigma on supply (Lena Edlund, Joseph Engelberg and Christopher Parsons 2009 on escorts and Sara Peracca, John Knodel and Chanpen Saengtienchai 1998 on Thai sex workers' ability to remarry), little work has addressed the effect it has on demand. Eileen V. Pitpitan et al. 2015 measure perceived stigma ${ }^{1}$ of purchasing sex among Latino and non-Latino male clients of female sex workers in Tijuana, Mexico. They find that stigma is higher among the Latino than the non -Latino population. Using

\footnotetext{
${ }^{1}$ Stigma is measured as an index based on the following 3 questions: "People will treat me differently if they find out that I go to prostitutes;" "Most people look down on men who go to prostitutes;" and "Most people think that men who go to prostitutes are bad people.'
} 
linear regression analyses, they found that perceived stigma was associated with greater guilt, a greater feeling of escape from everyday life, and more negative condom attitudes among Latino clients. These findings were not found among non-Latino clients.

The model of sex work proposed by Della Giusta et al. (2009a), is in the standard rational action tradition (based on the idea that agents make decisions based on the information available to them and having evaluated possible alternatives), but builds on the literature on social interactions (Mark Granovetter 1985; Pierre Bordieu 1986; James Coleman 1988; Charles Mansky 2000) and social sanctions (George Akerlof 1980; Richard Arnott and Joseph Stiglitz 1991), and discusses stigma as a loss of reputation which affects social standing for both clients and sex workers, as well as pay and working conditions in the sex trade and access to services and other jobs for sex workers. The model also incorporates personal differences in concern for reputation depending on agents' personal characteristics and the specific moment at which they exercise choice (so that people are allowed to differ and also to be inconsistent in their choices). This is important in order to describe situations of individuals with high reputation who disregard the effects of their actions, which would be otherwise construed as irrational behavior. We considered both the case in which reputational endowments are exogenous (that is not affected by behavior within the sex industry) and the situation when those endowments are considered endogenous, that is a situation in which if a higher quantity of sexual services is sold or bought in the economy the stigma effect decreases. Marina Della Giusta, Maria Laura Di Tommaso, Isilda Shima and Steinar Strøm (2009b) attempted to test some of the predictions of their model in an empirical exercise using data from a survey of US clients of street sex workers, which although wide in its scope contained only clients. In this paper, we look explicitly at how 
attitudes and risky behaviors affect demand for paid sex in a sample drawn from the British National Survey of Sexual Attitudes and Lifestyles (Natsal) conducted in 2000-2001 by the Centre for Sexual Health and HIV Research at University College London, interviewing 12,110 people aged 16-44 years. As this sample contains both clients and non-clients and is representative of the population, the results we infer are more robust for policy prescriptions because they can be generalised to the wider population. A set of recent studies conducted by Niklas Jakobsson and Andrea Kotsadam (2011) using Swedish and Norwegian data is to our knowledge the only other attempt at addressing the role of attitudes in demand for paid sex, and we compare wherever possible our results to theirs.

\section{The determinants of demand}

Findings from empirical studies of clients suggest that personal characteristics (personal and family background, self-perception, perceptions of women, sexual preferences), economic factors (education, income, work), as well as attitudes towards risk (health hazard and risk of being caught where sex work is illegal), lack of interest in conventional relationships, desire for variety in sexual acts or sexual partners, and viewing sex as a commodity, are all likely to affect demand. Cameron and Collins (2003) model male clients' decision to enter the market for sexual services, where he has the choice to derive utility from one relationship partner and/or one paid sex partner. They distinguish between the motivations of men in relationships (variety, specific acts, frequency, outlet for stress) and single men ('relative search costs of finding willing sexual partners, or partners willing to engage in specific sexual activities in an ad hoc or formal social context, and in a given time period.'). Marian Pitts, Anthony Smith, Mary O'Brien, and 
Sebastian Misson (2004) surveyed a sample of 1225 men and women in Australia $^{2}$ and found that $23.4 \%$ had paid for sex at least once. They reported paying for sex to satisfy sexual needs (43.8\%), because paying for sex is less trouble (36.4\%), and because it is entertaining (35.5\%). Significantly, the researchers found that there were not many significant differences between men who had paid for sex and those who had not, except that the ones who had were on average older, less likely to have university education and to have had a regular partner in the previous year.

The motivations of sex workers' clients in the UK have been the subject of extensive study by Teela Sanders in her Paying for Pleasure (2008), and included a wide range of issues including demand for variety but also difficulty with relationships and demand for companionship, and a widespread concern with shame, especially but not exclusively for those in relationships. Similar findings are reported by Maddie Coy, Miranda Horvath and Liz Kelly (2007) on buyers of sex in East London, ${ }^{3}$ as well as by Rosie Campbell (1998). This is confirmed by Thorbek and Pattanaik (2002), who draw a sort of "psychological" profile of male sex tourists on the basis of their own descriptions of themselves and accounts of their experiences. This indicates that many of them are finding relationships with others very difficult (either because they do not have the time or the skills required to meet people) and choose sex tourism as an "easier" alternative, which does not imply any responsibility towards the person providing the sexual service. As for the views

2

The sample was taken by distributing a survey to customers of a Sexpo exhibition hold in Melbourne in 2001.

This is a commercial event hosting a wide range of exhibitors of products associated with sex; of 4.905

respondents, 1225 received a version of the questionnaires with questions on sex workers. Among 1225

respondents, 612 were men and 601 were women.

3 http://www.cwasu.org/displayAuthorsPublications.asp?author_key=51 
they held of sex workers, it appears that both sexism and racism mix in determining a very marked distancing, which allow sex tourists to practically ignore and show no interest in the lives and working motivations of the sex workers whose services they buy.

Wider phenomena connected to consumerism and globalization are also clearly related to this industry, which reflects multiple power structures: Anna-Maria Marttila (2003) concludes from her study of Finnish clients that: "the sex business is first and foremost about gendered, economic, social and cultural - global and local - power structures.” (Marttila 2003, 8). Thus, different intersections of gender, race and class all contribute to the creation of 'othering' mechanisms that serve to both distance the parties to an exchange and justify the assertion of economic power within it. This phenomenon is obviously not limited to paid sex exchanges, and has been widely documented across a range of personal services.

Stigma is not just at play with men: women clients are also engaging in sex tourism, as documented both in Thorbek and Pattanaik (2002), and in Jacqueline Sanchez Taylor (2001). The latter, in particular, offers a more in-depth analysis of North American and Northern European women buying sex work services of young men in the Caribbean, in what they themselves describe as 'romance holidays'. Responses to her interviews suggest that, on the one hand, women clients are mostly reluctant to define what they engage in as sex work, and, on the other, that their ideas about the young men whose service they buy are deeply rooted in racist ideas about black men and black men's sexuality. The theme of inequality appears to be at the core of the relationship: prejudices that allow the stigmatization of another person as fundamentally “different" and inferior to oneself appear again and again in customers' accounts (Hanny BenIsrael and Numi Levenkron 2005; Pitts et al 2004; Roger Kern 2000; Karen Blanchard 1994). 
Studies have recently begun to appear that address more explicitly attitudes towards sex work and their relationship to regulatory regimes: Jari Kuosmanen (2011) reviews existing studies of attitudes to sex work in Sweden finding more support for criminalization as a result of the introduction of the law, and also conducts a random sample study finding more support for the current Swedish law among women and younger respondents and a small effect of higher education on women's attitudes. Jahnsen (2008), reviewed in Jakobsson and Kotsadam (2011) finds for Norway that women and those living in the capital region are more in favor of criminalizing clients, as are feminists, left-wing sympathizers, and Christians. Jakobsson and Kotsadam (2011) use data for Norway and Sweden find that men and sexual liberals are more positive toward sex work, that both conservatives and those supporting gender equality are more negative, and that holding anti-immigration views is correlated with more positive attitudes toward buying sex. These studies do not link attitudes towards sex work to the actual demand for paid sex because they do not have information about the demand for paid sex. Therefore, they cannot observe the correlation between holding conservative views and demand for paid sex but only between holding conservative views and attitudes towards sex work. In our paper, on the contrary, we can observe this correlation between having conservative views and demanding paid sex (see Section 4 and 5).

\section{The theoretical model}

The theoretical basis for the present paper is an economic model of sex work developed in Della Giusta et al (2009a), which incorporates both stigma and inequality between client and sex worker. Stigma is modelled as the effect on reputation from participating in this market, and we 
use insights on modelling reputations from both the economic and sociological literature (Granovetter, 1985; Bordieu, 1986; Coleman, 1988; Mansky, 2000), which point to two distinct ways in which reputations matter to economic agents: firstly, because as social beings they derive utility from a positive evaluation by others in the social groups they belong to (Mark Casson 1991), and secondly, because they are aware of the costs that social sanctions may impose on their material progress (Akerlof 1980; Arnott and Stiglitz 1991). Reputation has thus both intrinsic and instrumental value: it is desired per-se (provider of utility) and can be used to access other earning opportunities. Stigma is a loss of reputation, which can affect social standing. Following Akerlof (1980), we include reputation in agents' preferences in our model and allow agents to have a different concern for their reputation depending on their personal characteristics and the specific moment at which they exercise choice. The demand for sex in general and the demand for sex with a sex worker are not considered perfect substitutes reflecting the fact that clients' may have other motivations when buying sex, something we aim to explore empirically in the present paper.

Focusing on the demand side of the model, and following Della Giusta et al (2009b), let

$$
\mathrm{U}\left(\mathrm{S}_{0}, \mathrm{~S}, \mathrm{C}, \mathrm{r}, \mathrm{X}\right)
$$

denote the utility of buying sex. $\mathrm{S}_{0}$ is the amount of freely exchanged sex that the client has, whereas $\mathrm{S}$ is the amount of sex that the client has with sex workers. Amounts of sex can be measured in terms of number of sexual events (number of visits) during a certain period. $\mathrm{C}$ is consumption of other goods and services than sex, $\mathrm{r}$ is a variable related to reputation and stigma effects, and $\mathrm{X}$ is a vector of individual characteristics. The utility function is assumed to be increasing in $\left\{\mathrm{S}_{0}, \mathrm{~S}, \mathrm{C}, \mathrm{r}\right\}$ and strictly quasi-concave. 
Let $\mathrm{w}$ denote the price per event with a sex worker and let I denote disposable income. The budget constraint is given by

$$
\mathrm{I}=\mathrm{wS}+\mathrm{C} \text {. }
$$

We define a variable, $\mathrm{L}_{\mathrm{r}}$, as the capacity for reputational losses. $\mathrm{L}_{\mathrm{r}}$ is given for each individual and it depends on his professional status, his position in the community, and his marital status. A judge, a politician, or a priest has a low capacity for reputational losses (a low $\mathrm{L}_{\mathrm{r}}$ ) because he is vulnerable reputation-wise. Even a small amount of paid sex can ruin his reputation potential.

A high $\mathrm{L}_{\mathrm{r}}$ means that clients have little to lose reputation-wise i.e. they have a higher capacity for reputation losses. An individual with a low social status may have a high $\mathrm{L}_{\mathrm{r}}$.

A reputation loss can also include the intrinsic feelings of shame and guilt that result from buying sex, especially if the buyer is being unfaithful to a partner. Thus, we may assume that a partnered person has a lower capacity for reputational losses, $\mathrm{L}_{\mathrm{r}}$, than a single.

Individual reputation ( $\mathrm{r}$ ) is reduced when sex is bought in the market. We do not model the probability of being seen as a client; therefore, we assume that when sex is bought it is also observable in the community ${ }^{4}$. So we define individual reputation (r) equals to the capacity for reputational losses $\left(\mathrm{L}_{\mathrm{r}}\right)$ minus the amount of sex bought on the market $(\mathrm{S})$ :

${ }^{4}$ This is a limitation in our theoretical model. We could include in the model a probability of being caught. Then the capacity for reputational losses $\left(\mathrm{L}_{\mathrm{r}}\right)$ would not be reduced by the amount of paid sex (S) but by a probability of being caught. In the empirical part, this could be a function of the intensity of policing in different towns/districts. In UK, different districts have different regulations and different resources to contrast kerb crawling. Pitpitan et al. 2015 have found that 


$$
r=L_{r}-S
$$

Given that the utility function is assumed to be increasing in $\left\{S_{0}, S, C, r\right\}$ the higher the capacity for reputation loss $\left(\mathrm{L}_{\mathrm{r}}\right)$, the higher the utility. From (1) we note that paid sex and freely exchanged sex may be substitutes from a client's point of view.

Given that sex is bought, which means that the client has passed a threshold of buying sex, the amount of sex bought that maximizes utility (1) under the constraint (2) and (3) is given by the following demand function

$$
\mathrm{S}=\mathrm{f}\left(\mathrm{w}, \mathrm{I}, \mathrm{R}, \mathrm{S}_{0}, \mathrm{X}\right)
$$

Substituting the constraint 3 into 4 yields the reduced form:

$$
S=f\left(w, I, L_{r}, S_{0}, X\right)
$$

We thus expect that the amount of sex bought is decreasing in the price $\mathrm{w}$, increasing in income and in the capacity for reputation losses. If demand for paid sex decreases with regular sex, $\mathrm{S}_{0}$, paid sex and free sex are substitutes. Otherwise they are complements.

Della Giusta et al. (2009b) explored empirically whether the assumptions regarding the motivations for demand are valid, by developing an econometric model of client's demand with data from a US survey of clients of street sex workers. They analyzed the demand for paid sex using an ordered logit where the dependent variable was the number of times the client paid for sex in a year. Among the explanatory variables were personal characteristics, attitudes towards

Latino clients in Mexico who reported greater stigma also reported a greater preference of having sex with a female sex worker in a setting where there is risk of getting arrested, whereas nonLatino clients reported the opposite. 
sex workers, and preferences for relationships. The results of their empirical analysis confirm the behavioural assumptions behind the theoretical framework: stigmatisation of clients and sex workers are important characteristics of this market (as reflected in the attitudes of clients in the sample towards sex work, towards sex workers, and towards being caught), demand for paid and unpaid sex are indeed not perfect substitutes, they vary according to personal profiles and attitudes (especially regarding power asymmetries between clients and sex workers). There appear to be two distinct groups of clients whose personal characteristics and attitudes are radically opposite: experimenters, to whom street sex work is a complement to stable relationships, and who hold negative views of women, of sex work, and of sex workers; and regulars, who hold more liberal views, they like variety and find relationships a burden, and view paid sex as a normal good whose demand increases with income. The experimenters demand for sex increases with the need for control $^{5}$, while for regulars the opposite applies. Risk aversion is also correlated to our two client profiles, with experimenters being more risk loving and regulars more risk averse.

The main problem in Della Giusta et al. (2009b) is the selection bias in the data. In fact the data were collected among arrested male clients of female street sex workers in four USA cities (San Francisco, Portland, Las Vegas, Santa Chiara). Arrested clients who agreed to participate in an intervention program, were asked to fill a questionnaire. The data therefore had three levels of selection: individuals in the sample were the ones who were caught, agreed to participate to the re-habilitation program, and filled in the form. Therefore the results from that empirical study are strongly biased.

5 This is the clients' reply to the following question: “ Do you like to be in control when you are having sex?". For more details see Della Giusta et al. (2009b). 
The innovative approach of this paper consists in the use of a data set focusing on attitudes and risky behaviors that contains representative information of the entire British population, containing both clients and non-clients.

\section{Data set and modeling strategy}

In this paper we utilize the British National Survey of Sexual Attitudes and Lifestyles (Natsal II) conducted by the Centre for Sexual Health and HIV Research at University College London (http://www.ucl.ac.uk/sexual-health/research/sex-attitudes.htm). This is the second cross section of a series of surveys, of which the first was conducted in 1990-91. The sample size is 12,110 individuals aged 16-44 interviewed in the period 2000-2001, living in private households. The data were collected through face-to-face interviews.

For the purpose of this paper we selected only male individuals, because only men were asked whether they had paid for sex ${ }^{6}$. Moreover we selected only men between age 26 and 44 . We assume that young men could still be studying which could introduce some bias in the estimates of the education and professional variables. The resulting sample includes 3,084 observations.

As mentioned earlier, the main advantage of this data set with respect to the ones utilized for previous studies is that it is a national representative sample of sexual attitudes and it includes questions on paying for sex. This implies the possibility of studying clients versus non-clients

6

We underline that it would be important in the future to ask the same questions about paying for sex to women, given the increasing female demand for paid sex (Irmgard Bauer, 2014; Thorbek and Pattanaik; 200;, Sanchez Taylor; 2001). 
while most papers (including Della Giusta et al. 2009b) analyze clients with data sets that only contains clients. We define a client in our dataset as a man who declares to have paid for sex at least once. A drawback of our data is that there are no questions related to frequency of paid sexual encounters. The questions regard only if the (male) individual has ever paid for homosexual or heterosexual sex, and with how many sex workers ${ }^{7}$. In the following, we estimate a probit model where the dependent variable is equal to 1 if the man has ever paid for sex, and include all the variables reported in Table 1 as explanatory variables we discuss the chosen variables next. We also estimate a multinomial probit for three categories of men: non-clients, experimenter (paid to have sex with 1 person) and regulars (paid to have sex with more than 1 person), so we can check if our results are driven by experimenters or regulars.

In order to test the model presented in Section 3, we need some variables related to individual income, price of paid sex, capacity for reputation losses, amount of freely exchanged sex and other personal characteristics.

Unfortunately the British National Survey on Sexual Attitudes and Lifestyles does not contain data on income or price for paid sex. In order to have a proxy for income we use data on educational levels and number of children (a higher number of children implies less disposable income to be spent on paid sex). Educational is captured by four categories, reflecting the UK education system: university degree level qualification, A-levels (below higher education level but above high school level), O-levels (high school qualification level) and no education.

In addition, we assume that the variables related to professional status (captured by respondent's social class) are a proxy for reputation capacity or stigma. We assume that men with a high professional status (managers or professionals) have a small capacity for reputation losses

7 Table A1 in Appendix 1 show descriptive statistics for the total number of people paid for sex. 
$\left(\mathrm{L}_{\mathrm{r}}\right)$ and therefore that their reputations can be easily damaged. Professional status and educational levels are correlated but the correlation is not very high $^{8}$. In the estimated model, we provide different specifications excluding either professional status or educational level. We are aware that the estimation could suffer from omitted variables bias and therefore we include as a proxy for omitted variables also the professional status of men's parents (for the descriptive statistics of these variables see Table 1$){ }^{9}$

In order to test if paying for sex is correlated with risky behavior, we use five questions related to: sex with foreign partners, unsafe sex, smoking habits, use of injected drugs, and alcohol consumption.

The hypothesis that there is a correlation between demand for paid sex and free sex is tested using three variables: number of heterosexual partners in the last year, number of occasions of heterosexual sex in the last 4 weeks and a dummy for marriage or co-habitation.

Finally, we included some dummies for age of first heterosexual intercourse because the sociological literature on clients (Sanders 2008) shows that paying for sex is more frequent among those individuals who had their first intercourse at a younger age. We also included age of clients. We expect this variable to be positively correlated with paying for sex because in previous studies age was an important determinant of the demand for paid sex (Della Giusta et al 2009b).

8 See correlation matrix in Table A2 of Appendix 1

9 The parent's social class measure in the dataset had fewer categories than the respondents social class with partly skilled and unskilled group together, which as we did for own social class we grouped with the employed/unclassifiable category. 
Some descriptive statistics of our variables, with a split by clients and non -clients are provided in table 1 . We now discuss the main differences between clients and non-clients.

\section{TABLE 1 APPROXIMATLY HERE}

Men who have paid for sex constitute 12.9 percent of our sample. Since our sample is representative of the entire British population between age 26 and 44, we can infer that 13 percent of British men have paid for sex at least once in their life. Moreover, we notice that clients are on average 34.9 years old, while non-clients are on average 34.8 years old. Given that a client is defined as a man who has paid for sex at least once in his life, age is expected to be positively related to being a client. Nevertheless, the difference is small and not significantly

different from zero, probably because the sample only includes men below 44 years old. A previous study of US clients (Della Giusta et al 2009b) shows that age is positively correlated with paying for sex. We can therefore reasonably expect that if the dataset had included older men, the percentage of men who have ever paid for sex would increase above 13 percent.

Educational levels are different for clients and non-clients. Clients have higher levels of education with respect to non-clients, with clients (16 percent compared to 13 percent of nonclients) more likely to have A-levels or equivalent and the variable for no-education significantly different between client and non-clients. Among the clients only 13 percent do not have any education, while this is the case for 17 percent of the non-clients.

Table 1 also shows that there are more un-skilled and partly skilled among clients than among non-clients, even if the differences are only significantly different for the unskilled. For instance, 7 percent of the clients are unskilled, while this is the case for only 5 percent of the 
non-clients. We note, the higher the professional status, the higher the age of first heterosexual intercourse (see table A3 in appendix 1 for some descriptive statistics by professional status).

Clients have on average 0.3 children less than non-clients. Moreover, Table 1 shows that clients are on average less risk averse than non-clients (differences are statistically significant at the 1 percent level); they smoke more (45 percent of clients have smoked compared to 37 percent of non-clients), they had more unsafe sex last year (13 percent of clients against 6 percent of non-clients), and they use more drugs (6 percent of clients have ever injected drugs as opposed to 3 percent of non-clients). Clients are also on average more likely to have a high or medium level of alcohol consumption (19 percent as opposed to 13 percent).

Finally, 61 percent of clients are married or co-habiting as opposed to 75 percent of nonclients.

Clients had less heterosexual sex in the last 4 weeks (significantly different at the $10 \%$ level), but they had more sex partners in the last year.

\section{Results}

We utilize a probit model to estimate the probability of a man having ever paid for sex. The results of the probit model for demand of paid sex are reported in Table 2. We report the marginal effects, and the standard errors for three specifications of the model. Whilst one can interpret the sign and significance of the coefficients of a probit model, the magnitude of the raw coefficients are not intuitive, therefore we report average marginal effects (an average across marginal effects 
for each individual) which provides the effect of a change in an explanatory variable on the probability of having paid for sex.

Specification (1) include all the variables described in table 1; in order to test the interaction between education and professional status we also estimate two different specifications: in specification 2 and 3 we omit respectively education dummies and professional status dummies.

Results show that the model is robust to different specifications. The main differences between the three specifications consist of the magnitude for the education and professional status. This reduction in magnitude is due to the correlation between education and professional status and omitting one of them implies omitting relevant variables and introducing a bias. In commenting on the results, we concentrate on specification,1, our preferred specification.

\section{TABLE 2 APPROXIMATELY HERE}

Age has the expected (positive) sign which confirms previous results (Della Giusta et al. 2009b). Each year increases the probability of ever having paid for sex by 0.5 percent points. The positive effect of age does not necessarily means that older men demand more paid sex; this result could also be due to a longer spell of life for older men and therefore it is more likely that they have paid for sex in the course of their life.

One more child decreases the probability of having paid for sex by 1.4 percent points. This effect could be due to both an income effect and a time constraint.

The education dummies, that we use as a proxy for income, are significantly different from zero; having a university degree increases the probability of having paid for sex by 7 percent points with respect to those with no education; having O-levels (the equivalent of a high school 
diploma) increases the probability of having paid for sex by 4 percent points with respect to those with no education.

The variables related to the professional status show that the higher the status of the client, the lower the probability of paying for sex. These variables are interpreted in our models as representative of the reputation capacity $\left(\mathrm{L}_{\mathrm{r}}\right)$. In our theoretical model, we defined a capacity for reputational loss, which is lower for individuals with a high status (judges, politicians) than for others. In our empirical estimation, we interpret the negative sign associated with professional status as a confirmation that stigma and reputation matter for the demand for paid sex. Individuals with a professional/managerial position are 9 percentage points less likely to pay for sex than unskilled individuals.

The three different specifications show how the signs and significance for education and professional status variables do not change with the omission of either education or status. All the other coefficients do not change much across the three specifications.

The indicators for risky behavior show there is a high correlation among different types of risky behavior and paying for sex; for instance, smokers have a probability of paying for sex which is 2 percent points higher than for non-smokers (significant at the $10 \%$ level). Having injected drugs implies a probability of paying for sex which is 6 percent higher than for those who have not injected drugs. We find similar effects for alcohol consumption and unsafe sex.

We also find a negative and significant effect from the frequency of sex in the last 4 weeks, which confirms the hypothesis of a partial substitution effect between free and paid sex. The number of new heterosexual partners in the last year is positively and significantly related to the 
demand for paid sex, confirming that another component may be the desire for variety (as in Cameron and Collins, 2003). Being married or co-habiting is not statistically significant.

Having had the first intercourse between 13 and 15 years old increases the probability of having paid for sex by 5 percentage points.

Having conservative views regarding abortion, homosexuality or sex before marriage is not significantly correlated with having paid for sex. Also the effect on paying for sex of belonging to a religion is not significantly different from zero. These results confirm that there is often a double standard regarding attitudes towards sex work: while on one hand the most conservative groups hold the most prohibitionist views on sex work, on the other hand they do not demand less paid sex with respect to the less conservative groups in society. This is consistent with the view that while there are differences in attitudes between those who are religious and those who are not, there are no significant differences in their actions regarding paying for sex. This may be seen to run counter to the results in Jakobsson and Kotsadam (2011), who find a connection between degree of conservatism and views on sex work, though they do not connect degree of conservatism to actual demand as we are doing here. They test the effect of being religious and being from the right or the left on attitudes towards sex work among a representative sample of Norwegians and Swedes.

We also estimate a multinomial probit for three categories of men: non-clients, experimenter (paid to have sex with 1 person) and regulars (paid to have sex with more than 1 person), as a check to see if our results are driven by experimenters or regulars. Of our sample of clients, $41 \%$ are experimenters (164) and 59\% are regulars (234).

\section{TABLE 3 APPROXIMATLY HERE}


Table 3 shows the main results for this multinomial probit model for which we report average marginal effects. It seems that most of the results are driven by regulars rather than by experimenters, although those who have had unsafe sex or smoke are more likely to be experimenters whilst drugs and alcohol are more likely to be correlated with regulars.

Our results can be compared with Della Giusta et al. (2009b). The main difference between their model and the one presented in this paper is that we can include the category of non-clients. In terms of results, the main differences regard the professional status and the education variables. In Della Giusta et al (2009b) they were not significantly different from zero while, in table 3, we show that education is positively correlated with being a regular client and the higher the professional status the less likely is to be a regular client. Moreover, the added value of this model is to show that both education and professional status matters (in opposite ways) in order to enter the market (i.e. to become a client), as shown in the probit of table 2.

\section{Conclusion}

This paper builds on existing theoretical work on sex markets (Della Giusta, Di Tommaso, and Strøm, 2009a). Using data from the British Survey on Sexual Attitudes and Lifestyles for 2001, we replicate the analysis of the demand for paid sex previously conducted for the US (Della Giusta, Di Tommaso, Shima and Strøm, 2009b). In fact one of the main limitations of this previous paper was the lack of a national representative sample with data collected among clients who had been arrested and agreed to participate to a rehabilitation program. This self-selection problem meant the estimates were biased. The estimates presented in this paper are not biased in this way, because they are based on a national representative sample, which contains both clients and non-clients. In this representative sample, 13 percent of 
British men have paid for sex at least once in their lifetime. Moreover, the data set utilized in this paper allows us to explore the determinants for entering the market while the data utilized in previous papers could not.

We test the effect of attitudes, risky behaviors and personal characteristics on the demand for paid sex. Findings from empirical studies of clients suggest that personal characteristics (personal and family background, self-perception, perceptions of women, sexual preferences), economic factors (education, income, work) as well as attitudes towards risk (both health hazard and risk of being caught where sex work is illegal), and attitudes towards relationships and sex are all likely to affect demand. Previous theoretical work has argued that stigma plays a fundamental role in determining both demand and risk, and that, due to the presence of stigma effects when paying for sex, the demand for unpaid and paid sex is not, as argued elsewhere, perfect substitutes.

We find a positive effect of education (proxy for income). As for the variables that our theoretical model had focused on, we do indeed find that stigma matters as the dummy reflecting professional status is negatively and significantly related to demand suggesting that professionals may indeed worry about the effect of paying for sex on their reputation. Risky behaviours are found to be positively and significantly related to demand; alcohol use, unsafe sex, smoking and drugs use are all positively and significantly related to demand for paid sex, which confirms the view that part of the demand is motivated by the thrill of engaging in risky behavior. We also find no significant effects of variables which measure the relative degree of conservatism in morals. 
The policy implications from these findings are not straightforward and more analysis is needed to be able to offer robust suggestions. However, it seems clear that stigma plays a role in demand (at least the stigma potentially suffered by a client), as does attitudes to risk.

\section{Bibliography}

Akerlof, George A. 1980. "A Theory of Social Custom - of which Unemployment may be One Consequence", Quarterly Journal of Economics 94(4): 749-775.

Arnott, Richard and Joseph. E. Stiglitz. 1991. "Equilibrium in Insurance Markets with Moral Hazard”, Working Paper No. 3588 (Cambridge, MA: National Bureau of Economic Research).

\section{Agustin Laura. 2007. Sex at the Margins: Migration, Labour Markets and the Rescue} Industry, Zed Books.

Bauer, Irmgard. 2014. "Romance tourism or female sex tourism?", Travel Medicine and Infectious Disease, 12(1): 20-28

Beauvoir, Simone. 1949 “The Second Sex”, Vintage Books

Ben-Israel, Hanny and Numi Levenkron. 2005. "The Missing Factor: Clients of Trafficked Women in Israel's Sex Industry", unpublished manuscript, Hebrew University in Jerusalem.

Blanchard, Karen. 1994. "Young Johns", Mademoiselle, 100(5)

Bordieu, Pierre. 1986. "The Forms of Capital”, in Richardson J.G. (ed.), Handbook of Theory

and Research for the Sociology of Education (Westport: Greenwood), 241-258.

Brewis, Joanna and Stephen Linstead. 2000. "The Worst Thing is the Screwing': Context and Career in Sex Work", Gender, Work and Organization, 7 (3): 168-180 
Cameron, Samuel. 2002 "The Economics of Sin”, Cheltenham: Edward Elgar.

Cameron, Samuel and Alan Collins. 2003. "Estimates of a Model of Male Participation in the

Market for Female Heterosexual Prostitution Services," European Journal of Law and

Economics 16(3): 271-288.

Cameron, Samuel, Alan Collins and Neill Thew. 1999. "Prostitution Services: An Exploratory Empirical Analysis," Applied Economics 31(12), 1523-1529.

Campbell, Rosie. 1998. "Invisible men: making visible male clients of female prostitutes in Merseyside.”, in Prostitution: On Whores, Hustlers and Johns, Prometheus, Amsherst, NY.

Casson, Mark. 1991. "The Economics of Business Culture”, Oxford: Clarendon Press.

Coleman, James. 1988. "Social Capital in the Creation of Human Capital”, American Journal of Sociology, 94: 95-120.

Collins, Alan (ed). 2004. "Sex and the City”,' Urban Studies, 41(9)

Coy, Maddie, Miranda Horwarth and Liz Kelly. 2007. "It's just like going to the supermarket: Men talk about buying sex in East London”. Child and Woman Abuse Studies Unit, London.

Cunningham, Scott and Todd D. Kendall. 2011. "Men in Transit and Prostitution: Using Political Conventions as a Natural Experiment," The B.E. Journal of Economic Analysis \& Policy: 11(1): Article 30. 
Della Giusta, Marina, Maria Laura Di Tommaso, and Steinar Strøm. 2009a. "Who is Watching? The market for prostitution services", Journal of Population Economics, 22 (2): 501-516.

Della Giusta, Marina, Maria Laura Di Tommaso, Isilda Shima and Steinar Strøm. 2009b. "What money buys: clients of street sex workers in the US", Applied Economics, 41 (18): 2261-2278.

Della Giusta, Marina. 2010 "Simulating the Impact of Regulation Changes on the Market for Prostitution Services", European Journal of Law and Economics, 29(1): 1-14

Della Giusta, Marina and Vanessa E. Munro. (eds.) 2008. "Demanding sex; Critical reflections on the regulation of prostitution", Ashgate, UK

Di Tommaso, Maura Laura, Isilda Shima, Steinar Strøm and Francesca Bettio. 2009. As bad as it gets. Well-being deprivation of sexually exploited trafficked women. European Journal of Political Economy, 25: 143-162.

Edlund, Lena, Joseph Engelberg and Christopher Parsons. 2009. "The Wages of Sin," Discussion Papers 0809-16, Columbia University, Department of Economics.

Edlund, Lena and Evelyn Korn. 2002. "An Economic Theory of Prostitution”, Journal of Political Economy 110 (1): 181-214.

Farmer, Amy and Andrew. W. Horowitz. 2013. "Prostitutes, Pimps and Brothels: Intermediaries, Information, and Market Structure in Prostitution Markets" Southern Economic Journal 2013, 79(3): 513-528

Gertler, Paul, Manisha Shah and Stefano Bertozzi et al. 2003. "Risky Business: the Market for Unprotected Prostitution", Mimeo: Cornell University 
Granovetter, Mark. 1985. "Economic Action and Social Structure: The Problem of Embeddedness", American Journal of Sociology 91(3): 481-510.

Hui, Neha. 2012. “Adoption of Transactions Costs Approach to Brothel -Based Sex Work: Case of GB Road, New Delhi, India”, The Indian Journal of Labour Economics, 55 (3)

Jakobsson, Niklas and Andreas Kotsadam. 2011. "Gender Equity and Prostitution: An Investigation of Attitudes in Norway and Sweden" Feminist Economics, 17(1): 31-58. Kempadoo Kamala, Jyoti Sanghera, Bandana Pattanaik 2011. Trafficking and Prostitution Reconsidered, Second Edition: New Perspectives on Migration, Sex Work, and Human Rights Paradigm Publishers

Kern, Roger. M. 2000. "Prostitute Client Profiles: Indicators of Motivations for Prostitution Use”, Archives of Sexual Behaviour 29 (2): 165-177.

Kuosmanen, Jari. 2011. "Attitudes and perceptions about legislation prohibiting the purchase of sexual services in Sweden", European journal of social work, 14 (2): 247-263

Marttila, Anna-Maria. 2003. "Consuming Sex: Finnish Male Clients and Russian and Baltic Prostitution", Presented at Gender and Power in the New Europe, the 5th European Feminist Research Conference August 20-24, 2003 Lund University, Sweden.

Mansky, Charles. 2000. "Economic Analysis of Social Interactions", Journal of Economic Perspectives 14(3): 114-136

Moffatt, Peter. G. and Simon Peters. 2001. “The Pricing of Personal Services”, Mimeo: Royal

Economic Society in Durham, Apr. 2001 
National Centre for Social Research et al. , National Survey of Sexual Attitudes and Lifestyles II, 2000-2001 [computer file]. Colchester, Essex: UK Data Archive [distributor], August 2005. SN: 5223.

Nussbaum, Martha. 1999. "Sex and Social Justice”, New York: Oxford University Press.

O'Connell Davidson, Julia. 2014. " Let's go outside: bodies, prostitutes, slaves and worker citizens" Citizenship Studies,18(5), 516-532.

Pateman, Caroline. 1983. "Defending Prostitution: Charges Against Ericsson”, Ethics, 93(3), $561-565$

Peracca, Sara, John Knodel and Chanpen Saengtienchai. 1998. "Can prostitutes marry? Thai attitudes toward female sex workers", Social Science \& Medicine, 47(2): 255-267

Pheterson Gail. 1995. The prostitution Prism. Amsterdam Univ Pr. Amsterdam.

Pitpitan, Eileen V., Steffanie A. Strathdee, Shirley J. Semple, Karla D. Wagner - Claudia V. Chavarin, Valerie A. Earnshaw, Thomas L. Patterson. 2015 "Perceived Stigma of Purchasing Sex Among Latino and Non-Latino Male Clients of Female Sex Workers in Tijuana, Mexico", Immigrant Minority Health, 17, 172-180

Pitts, Marian K., Anthony M.A. Smith, Mary O’Brien, and Sebastian Misson. 2004. "Who pays for sex and why? An analysis of social and motivational factors associated with male clients of sex workers", Archives of Sexual Behaviour, 33 (4): 353-358.

Rao, Vijayendra, Indrani Gupta, Michael Lokshin and Smarajit Jana. 2001. "Sex Workers and the Cost of Safe Sex: The compensating Differential for Condom Use in Calcutta", Mimeo: World Bank 
Sanchez Taylor, Jacqueline. 2001. "Dollars are a Girl's Best Friend? Female Tourists' Sexual Behaviour in the Caribbean”, Sociology: Identity Politics in the Workplace 3 (3): 749-764.

Sanchez Taylor, Jacqueline. and O'Connell Davidson, Julia, 2010. Unknowable secrets and golden silence: reflexivity and research on sex tourism. In: R. RYAN-FLOOD and R. GILL, eds., Secrecy and Silence in the Research Process: feminist reflections London: Routledge. 42-53

Sanders, Teela. 2008. "Paying for Pleasure: Men who buy sex”, Willan, Cullompton.

Satz, Debra. 2010. “Why Some Things Should Not be for Sale: Moral Limits of Market”, Oxford University Press, New York

Scoular, Jane. 2010. "What's Law Got To Do With It? How and Why Law Matters in the Regulation of Sex Work", Journal of Law and Society, 37 (1): 12-39

Thorbek, Susanne and Bandana Pattanaik. (eds.) 2002. "Transnational Prostitution: Changing Global Patterns", London: Zed Books

Vanwesenbeeck, Ine. 2001. "Another Decade of Research in Social Scientific Work on Sex Work: A Review of Research: 1990-2000”, Annual Review of Sex Research, 12: 242-289

Weitzer, Ronald 2014. "New Directions in Research on Human Trafficking," The ANNALS of the American Academy of Political and Social Science, v. 653 (May): 6-24

Weitzer, Ronald. 2015a. "Researching Prostitution and Sex Trafficking Comparatively". Sexuality Research and Social Policy, 12 (2), 81-91

Weitzer, Ronald. 2015b "Human Trafficking and Contemporary Slavery." Annual Review of Sociology 41 
Table 1: Average values of the variables used in the probit of table 2 for 399 clients and 2685 non-clients (3084 British men).

\begin{tabular}{|c|c|c|c|c|c|c|c|}
\hline & \multicolumn{4}{|c|}{ All } & \multicolumn{2}{|c|}{ Means } & \\
\hline & Mean & St.Dev & Min & Max & Clients & $\begin{array}{l}\text { Non- } \\
\text { client }\end{array}$ & \\
\hline Age & 34.81 & 5.25 & 26 & 44 & 34.89 & 34.8 & \\
\hline Number of children & 1.15 & 1.26 & 0 & 8 & 0.89 & 1.19 & $* * *$ \\
\hline \multicolumn{8}{|l|}{ Education dummies } \\
\hline$=1$ if degree level qualification; $=0$ otherwise & 0.27 & 0.45 & 0 & 1 & 0.3 & 0.27 & \\
\hline $\begin{array}{l}=1 \text { if a-levels/as-levels/slc higher grade } ;=0 \\
\text { otherwise }\end{array}$ & 0.12 & 0.32 & 0 & 1 & 0.16 & 0.11 & $* * *$ \\
\hline$=1$ if o-level/other; $=0$ otherwise & 0.44 & 0.5 & 0 & 1 & 0.42 & 0.44 & \\
\hline$=1$ if no education; $=0$ otherwise & 0.17 & 0.37 & 0 & 1 & 0.13 & 0.17 & $* *$ \\
\hline \multicolumn{8}{|l|}{ Professional status } \\
\hline$=1$ if professional $/$ managerial; $=0$ otherwise & 0.09 & 0.29 & 0 & 1 & 0.08 & 0.09 & \\
\hline$=1$ if technical $/$ managerial $;=0$ otherwise & 0.34 & 0.47 & 0 & 1 & 0.34 & 0.34 & \\
\hline$=1$ if skilled manual or non-manual; $=0$ otherwise & 0.41 & 0.49 & 0 & 1 & 0.39 & 0.41 & \\
\hline$=1$ if partly skilled; $=0$ otherwise & 0.11 & 0.32 & 0 & 1 & 0.13 & 0.11 & \\
\hline$=1$ if unskilled; $=0$ otherwise & 0.05 & 0.21 & 0 & 1 & 0.07 & 0.05 & $* *$ \\
\hline \multicolumn{8}{|l|}{ Risky behavior } \\
\hline $\begin{array}{l}=1 \text { if had partner outside UK in the last } 5 \text { years; }=0 \\
\text { otherwise }\end{array}$ & 0.14 & 0.35 & 0 & 1 & 0.33 & 0.11 & $* * *$ \\
\hline$=1$ if had unsafe het. sex in last year; $=0$ otherwise & 0.07 & 0.25 & 0 & 1 & 0.13 & 0.06 & $* * *$ \\
\hline$=1$ if ever a smoker; $=0$ otherwise & 0.38 & 0.49 & 0 & 1 & 0.45 & 0.37 & $* * *$ \\
\hline $\begin{array}{l}=1 \text { if ever injected drugs or other substances; }=0 \\
\text { otherwise }\end{array}$ & 0.03 & 0.18 & 0 & 1 & 0.06 & 0.03 & $* * *$ \\
\hline $\begin{array}{l}=1 \text { if high or medium alcohol consumption; }=0 \\
\text { otherwise }\end{array}$ & 0.14 & 0.35 & 0 & 1 & 0.2 & 0.13 & $* * *$ \\
\hline \multicolumn{8}{|l|}{ Free sex } \\
\hline Number of new het. sex partners, last year & 0.57 & 1.82 & 0 & 55 & 1.35 & 0.45 & $* * *$ \\
\hline Number of occasions of het. sex in last 4 weeks & 5.49 & 6.01 & 0 & 56 & 5.12 & 5.54 & $*$ \\
\hline $\begin{array}{l}=1 \text { if married or cohabiting or widow or divorced; } \\
=0 \text { if single } \& \text { never married }\end{array}$ & 0.73 & 0.44 & 0 & 1 & 0.61 & 0.75 & $* * *$ \\
\hline \multicolumn{8}{|l|}{ Conservative opinions/religion } \\
\hline$=1$ if belongs to any religion now; $=0$ otherwise & 0.45 & 0.5 & 0 & 1 & 0.46 & 0.44 & \\
\hline $\begin{array}{l}=1 \text { if sex before marriage always, mostly or } \\
\text { sometimes wrong; }=0 \text { otherwise }\end{array}$ & 0.15 & 0.36 & 0 & 1 & 0.13 & 0.15 & \\
\hline $\begin{array}{l}=1 \text { if sex between } 2 \text { men always, mostly or } \\
\text { sometimes wrong; }=0 \text { otherwise }\end{array}$ & 0.54 & 0.5 & 0 & 1 & 0.52 & 0.55 & \\
\hline$=1$ if abortion always or mostly wrong; $=0$ otherwise & 0.3 & 0.46 & 0 & 1 & 0.27 & 0.3 & $*$ \\
\hline \multicolumn{8}{|l|}{ Age at first het. intercourse } \\
\hline Aged 13-15 & 0.26 & 0.44 & 0 & 1 & 0.34 & 0.24 & $* * *$ \\
\hline Aged 16-17 & 0.38 & 0.49 & 0 & 1 & 0.32 & 0.39 & $* * *$ \\
\hline Aged 18-19 & 0.2 & 0.4 & 0 & 1 & 0.19 & 0.2 & \\
\hline
\end{tabular}


Aged 20+

Parent's professional status

$=1$ if $\mathrm{professional} / \mathrm{managerial} ;=0$ otherwise

$=1$ if technical $/$ managerial $;=0$ otherwise

$=1$ if skilled manual or non-manual $;=0$ otherwise

$=1$ if other; $=0$ otherwise

\section{Dependent variable}

$=1$ if ever paid for sex; $=0$ otherwise $\begin{array}{llllll}0.16 & 0.37 & 0 & 1 & 0.15 & 0.16\end{array}$

$\begin{array}{llllll}0.17 & 0.38 & 0 & 1 & 0.18 & 0.17\end{array}$

$\begin{array}{llllll}0.18 & 0.38 & 0 & 1 & 0.24 & 0.17\end{array}$

$\begin{array}{lllll}0.38 & 0.49 & 0 & 1 & 0.36\end{array}$

$\begin{array}{lllll}0.26 & 0.44 & 0 & 1 & 0.23\end{array}$

0.39

0.27

0.34

0

Other for the parent's professional status includes partly skilled, unskilled, unemployed and unclassifiable $* \mathrm{p}<0.1, * * \mathrm{p}<0.05, * * * \mathrm{p}<0.01$; significantly different between client and non-client 


\begin{tabular}{|c|c|c|c|}
\hline Dependent variable $=1$ if ever paid for sex; $=0$ otherwise. & All & $\begin{array}{l}\text { No } \\
\text { education }\end{array}$ & $\begin{array}{l}\text { No } \\
\text { Professional } \\
\text { Status } \\
\end{array}$ \\
\hline \multirow[t]{2}{*}{ Age } & $0.005 * * *$ & $0.005^{* * *}$ & $0.005 * * *$ \\
\hline & {$[0.001]$} & {$[0.001]$} & {$[0.001]$} \\
\hline \multirow[t]{2}{*}{ Number of children } & $-0.014 * *$ & $-0.015^{* *}$ & $-0.014 * *$ \\
\hline & {$[0.006]$} & {$[0.006]$} & {$[0.006]$} \\
\hline \multicolumn{4}{|l|}{ Education dummies } \\
\hline \multirow[t]{2}{*}{$=1$ if degree level qualification; $=0$ otherwise } & $0.070 * * *$ & & $0.048^{* *}$ \\
\hline & {$[0.023]$} & & [0.021] \\
\hline \multirow[t]{2}{*}{$=1$ if a-levels/as-levels/slc higher grade; $=0$ otherwise } & $0.081 * * *$ & & $0.069 * * *$ \\
\hline & {$[0.023]$} & & {$[0.023]$} \\
\hline \multirow[t]{2}{*}{$=1$ if o-level/other; $=0$ otherwise } & $0.042 * *$ & & $0.036^{* *}$ \\
\hline & {$[0.018]$} & & {$[0.018]$} \\
\hline \multicolumn{4}{|l|}{ Professional status } \\
\hline \multirow[t]{2}{*}{$=1$ if professional $/$ managerial; $=0$ otherwise } & $-0.094 * * *$ & $-0.069 * *$ & \\
\hline & {$[0.033]$} & [0.032] & \\
\hline \multirow[t]{2}{*}{$=1$ if technical $/$ managerial $;=0$ otherwise } & $-0.077 * * *$ & $-0.055^{* *}$ & \\
\hline & {$[0.027]$} & {$[0.026]$} & \\
\hline \multirow[t]{2}{*}{$=1$ if skilled manual or non-manual; $=0$ otherwise } & $-0.062 * *$ & $-0.055^{* *}$ & \\
\hline & {$[0.026]$} & {$[0.025]$} & \\
\hline \multirow[t]{2}{*}{$=1$ if partly skilled; $=0$ otherwise } & -0.041 & -0.039 & \\
\hline & {$[0.029]$} & [0.029] & \\
\hline \multicolumn{4}{|l|}{ Risky behavior } \\
\hline \multirow[t]{2}{*}{$=1$ if had partner outside UK in the last 5 years; $=0$ otherwise } & $0.122 * * *$ & $0.123 * * *$ & $0.122 * * *$ \\
\hline & {$[0.015]$} & {$[0.015]$} & [0.015] \\
\hline \multirow[t]{2}{*}{$=1$ if had unsafe het. sex in last year; $=0$ otherwise } & $0.061 * * *$ & $0.060 * * *$ & $0.064 * * *$ \\
\hline & {$[0.020]$} & {$[0.020]$} & {$[0.020]$} \\
\hline \multirow[t]{2}{*}{$=1$ if ever a smoker; $=0$ otherwise } & $0.021 *$ & 0.016 & $0.023^{*}$ \\
\hline & {$[0.012]$} & {$[0.012]$} & [0.012] \\
\hline \multirow[t]{2}{*}{$=1$ if ever injected drugs or other substances; $=0$ otherwise } & $0.063 * *$ & $0.060 * *$ & $0.062 * *$ \\
\hline & {$[0.028]$} & {$[0.028]$} & {$[0.028]$} \\
\hline \multirow[t]{2}{*}{$=1$ if high or medium alcohol consumption; $=0$ otherwise } & $0.037 * *$ & $0.037 * *$ & $0.036^{* *}$ \\
\hline & {$[0.016]$} & {$[0.016]$} & {$[0.016]$} \\
\hline \multicolumn{4}{|l|}{ Free sex } \\
\hline \multirow[t]{2}{*}{ Number of new het. sex partners, last year } & $0.010 * * *$ & $0.010 * * *$ & $0.010 * * *$ \\
\hline & {$[0.003]$} & {$[0.003]$} & {$[0.003]$} \\
\hline \multirow[t]{2}{*}{ Number of occasions of het. sex in last 4 weeks } & $-0.002 * *$ & $-0.002 * *$ & $-0.002 * *$ \\
\hline & {$[0.001]$} & {$[0.001]$} & {$[0.001]$} \\
\hline$=1$ if married or cohabiting or widow or divorced; & -0.016 & -0.019 & -0.02 \\
\hline$=0$ if single $\&$ never married & {$[0.015]$} & {$[0.015]$} & [0.015] \\
\hline
\end{tabular}

Conservative opinions/religion 


\begin{tabular}{|c|c|c|c|}
\hline \multirow[t]{2}{*}{$=1$ if belongs to any religion now; $=0$ otherwise } & 0.015 & 0.018 & 0.014 \\
\hline & {$[0.012]$} & {$[0.012]$} & {$[0.012]$} \\
\hline \multirow{2}{*}{$=1$ if sex before marriage always, mostly or sometimes wrong $;=0$ otherwise } & -0.003 & 0 & -0.001 \\
\hline & {$[0.018]$} & {$[0.018]$} & {$[0.018]$} \\
\hline \multirow[t]{2}{*}{$=1$ if sex between 2 men always, mostly or sometimes wrong; $=0$ otherwise } & 0.007 & 0.002 & 0.009 \\
\hline & {$[0.013]$} & {$[0.012]$} & {$[0.013]$} \\
\hline \multirow[t]{2}{*}{$=1$ if abortion always or mostly wrong; $=0$ otherwise } & -0.006 & -0.009 & -0.005 \\
\hline & {$[0.014]$} & {$[0.014]$} & {$[0.014]$} \\
\hline \multicolumn{4}{|l|}{ Age at first het. intercourse } \\
\hline \multirow[t]{2}{*}{ Aged 13-15 } & $0.050 * * *$ & $0.048 * * *$ & $0.053 * * *$ \\
\hline & {$[0.015]$} & {$[0.015]$} & {$[0.015]$} \\
\hline \multirow[t]{2}{*}{ Aged 18-19 } & 0.004 & 0.008 & 0.004 \\
\hline & {$[0.016]$} & {$[0.017]$} & {$[0.017]$} \\
\hline \multirow[t]{2}{*}{ Aged 20+ } & 0.007 & 0.011 & 0.009 \\
\hline & {$[0.018]$} & {$[0.018]$} & {$[0.018]$} \\
\hline \multicolumn{4}{|l|}{ Parent's professional status } \\
\hline \multirow[t]{2}{*}{$=1$ if professional $/$ managerial $;=0$ otherwise } & 0.01 & 0.022 & 0.007 \\
\hline & {$[0.019]$} & {$[0.019]$} & {$[0.019]$} \\
\hline \multirow[t]{2}{*}{$=1$ if technical $/$ managerial; $=0$ otherwise } & $0.037 *$ & $0.047^{* *}$ & $0.033^{*}$ \\
\hline & {$[0.019]$} & {$[0.019]$} & {$[0.019]$} \\
\hline \multirow[t]{2}{*}{$=1$ if skilled manual or non-manual; $=0$ otherwise } & 0.005 & 0.009 & 0.005 \\
\hline & {$[0.014]$} & {$[0.014]$} & {$[0.015]$} \\
\hline Observations & 3,084 & 3,084 & 3,084 \\
\hline Log likelihood & -1071 & -1078 & -1077 \\
\hline LR Chi2 & 233 & 219.1 & 222.9 \\
\hline pseudo r-squared & 0.0981 & 0.0922 & 0.0938 \\
\hline
\end{tabular}

Standard errors in brackets

*** $\mathrm{p}<0.01, * * \mathrm{p}<0.05, * \mathrm{p}<0.1$

Base category: No education, No skilled, Aged 16-17, other

Table 3: Multinomial Probit Results of Non-Clients (2,685 men), Experimenters (165 men) and Regulars (234 men): Average Marginal Effects

\begin{tabular}{llll} 
& Never paid for sex & Experimenter & Regular \\
\hline Age & $-0.005 * * *$ & 0.001 & $0.004 * * *$ \\
& {$[0.001]$} & {$[0.001]$} & {$[0.001]$} \\
Number of children & $0.014 * *$ & -0.005 & $-0.009 *$ \\
& {$[0.006]$} & {$[0.004]$} & 0.016 \\
Education dummies & $-0.071^{* * *}$ & $0.005]$ & $0.055^{* * *}$ \\
$=1$ if degree level qualification; $=0$ otherwise & {$[0.023]$} & {$[0.016]$} & {$[0.018]$} \\
& $-0.079 * * *$ & $0.035^{* *}$ & $0.044 * *$
\end{tabular}


$=1$ if $\mathrm{o}-$ level/other; $=0$ otherwise

Professional status

$=1$ if professional $/$ managerial; $=0$ otherwise

$=1$ if technical $/$ managerial $;=0$ otherwise

$=1$ if skilled manual or non-manual; $=0$ otherwise

$=1$ if partly skilled; $=0$ otherwise

Risky behavior

$=1$ if had partner outside UK in the last 5 years; $=0$ otherwise

$=1$ if had unsafe het. sex in last year; $=0$ otherwise

$=1$ if ever a smoker; $=0$ otherwise

$=1$ if ever injected drugs or other substances; $=0$ otherwise

$=1$ if high or medium alcohol consumption; $=0$ otherwise

Free sex

Number of new het. sex partners, last year

Number of occasions of het. sex in last 4 weeks

$=1$ if married or cohabiting or widow or divorced;

$=0$ if single $\&$ never married

\section{Conservative opinions/religion}

$=1$ if belongs to any religion now; $=0$ otherwise

$=1$ if sex before marriage always, mostly or sometimes wrong; $=0$ otherwise

$=1$ if sex between 2 men always, mostly or sometimes wrong; $=0$ otherwise

$=1$ if abortion always or mostly wrong; $=0$ otherwise

\section{Age at first het. intercourse}

Aged 13-15

Aged 18-19
[0.023]

$-0.042 * *$

[0.018]

$0.096 * * *$

[0.034]

$0.077 * * *$

[0.027]

$0.062 * *$

[0.026]

0.041

[0.029]

$-0.121 * * *$

[0.015]

$-0.060 * * *$

[0.020]

$-0.02$

[0.012]

$-0.061 * *$

[0.028]

$-0.038 * *$

[0.016]

$0.002 * *$

[0.001]

$-0.011 * *$

[0.005]

0.016

[0.015]

$-0.016$

[0.012]

0.005

[0.019]

$-0.007$

[0.013]

0.005

[0.014]

$-0.051 * * *$

[0.015]

$-0.005$
[0.016]

[0.019]

0.012

0.030 **

[0.012]

[0.015]

$-0.035$

[0.025]

$-0.061 * *$

[0.025]

$-0.019$

$-0.058 * * *$

[0.019]

[0.021]

$-0.052 * * *$

[0.019]

[0.018]

$-0.046^{* *}$

0.005

[0.022]

[0.020]

$0.035 * * *$

$0.086^{* * *}$

[0.010]

[0.011]

$0.030 * *$

$0.029 *$

[0.013]

[0.016]

$0.022 * * *$

$-0.002$

[0.008]

[0.010]

0.008

$0.054 * * *$

[0.020]

[0.021]

0.008

0.030 **

[0.011]

[0.012]

$-0.002 * * \quad 0$

[0.001] [0.001]

$-0.011 * * \quad-0.012 * *$

[0.005]

[0.005]

$-0.005$

$-0.011$

[0.010]

[0.012]

0.011

0.004

[0.008]

[0.010]

$-0.022$

0.017

[0.014]

[0.014]

0.001

0.006

[0.009]

[0.010]

$-0.002$

$-0.003$

[0.009]

[0.011]

0.008

$0.044 * * *$

[0.010]

[0.012]

$-0.017$ 


\begin{tabular}{|c|c|c|c|}
\hline \multirow{3}{*}{ Aged 20+ } & [0.017] & {$[0.012]$} & [0.013] \\
\hline & -0.006 & -0.019 & $0.026^{*}$ \\
\hline & [0.019] & {$[0.014]$} & [0.014] \\
\hline \multicolumn{4}{|l|}{ Parent's professional status } \\
\hline \multirow[t]{2}{*}{$=1$ if professional $/$ managerial $;=0$ otherwise } & -0.011 & $0.029 * *$ & -0.018 \\
\hline & [0.019] & {$[0.014]$} & [0.014] \\
\hline \multirow{2}{*}{$=1$ if technical $/$ managerial $;=0$ otherwise } & $-0.038 * *$ & $0.028 * *$ & 0.01 \\
\hline & [0.019] & {$[0.013]$} & [0.015] \\
\hline \multirow[t]{2}{*}{$=1$ if skilled manual or non-manual; $=0$ otherwise } & -0.005 & 0.008 & -0.003 \\
\hline & {$[0.014]$} & {$[0.009]$} & [0.012] \\
\hline Observations & 3,084 & 3,084 & 3,084 \\
\hline Log likelihood & -1071 & -1078 & -1077 \\
\hline LR Chi2 & 233 & 219.1 & 222.9 \\
\hline pseudo r-squared & 0.0981 & 0.0922 & 0.0938 \\
\hline
\end{tabular}

Standard errors in brackets

*** $\mathrm{p}<0.01, * * \mathrm{p}<0.05, * \mathrm{p}<0.1$

Base category: No education, No skilled, Aged 16-17, other

\section{APPENDIX 1}

Table A1: descriptive statistics for the total number of people paid for sex.

\begin{tabular}{|r|r|r|}
\hline & Freq. & Percent \\
\hline 0 & 2,685 & 87.06 \\
\hline 1 & 165 & 5.35 \\
\hline 2 & 74 & 2.4 \\
\hline 3 & 48 & 1.56 \\
\hline 4 & 25 & 0.81 \\
\hline 5 & 22 & 0.71 \\
\hline 6 & 15 & 0.49 \\
\hline 7 & 12 & 0.39 \\
\hline 8 & 8 & 0.26 \\
\hline 10 & 9 & 0.29 \\
\hline 12 & 4 & 0.13 \\
\hline 15 & 3 & 0.1 \\
\hline 20 & 6 & 0.19 \\
\hline 21 & 2 & 0.06 \\
\hline 25 & 2 & 0.06 \\
\hline 32 & 1 & 0.03 \\
\hline
\end{tabular}




\begin{tabular}{|r|r|r|}
40 & 1 & 0.03 \\
\hline 50 & 1 & 0.03 \\
\hline 150 & 1 & 0.03 \\
\hline & & \\
\hline Total & 3,084 & 100 \\
\hline
\end{tabular}

Table A2: Correlation matrix between Professional status and educational levels.

\begin{tabular}{|l|l|l|l|l|}
\hline & Degree level & A-level & O-level/other & None \\
\hline Professional/managerial & $0.3680^{*}$ & $-0.0622^{*}$ & $-0.1936^{*}$ & $-0.1314^{*}$ \\
\hline Managerial/technical & $0.2935^{*}$ & $0.1125^{*}$ & $-0.1708^{*}$ & $-0.2213^{*}$ \\
\hline Skilled & $-0.3263^{*}$ & -0.0243 & $0.2186^{*}$ & $0.1228^{*}$ \\
\hline Part skilled & $-0.1772^{*}$ & $-0.0500^{*}$ & $0.0736^{*}$ & $0.1568^{*}$ \\
\hline Unskilled & $-0.1289^{*}$ & $-0.0343^{*}$ & 0.027 & $0.1471^{*}$ \\
\hline
\end{tabular}

Table A3: Descriptive statistics of select variables by professional status

\begin{tabular}{|c|c|c|c|c|c|c|}
\hline & Professional & managerial/technical & Skilled & $\begin{array}{l}\text { Part } \\
\text { skilled }\end{array}$ & Unskilled & Total \\
\hline Number of occasions of het. sex in last 4 weeks & 5.24 & 5.18 & 5.52 & 4.72 & 5.48 & 5.28 \\
\hline Number of new het. sex partners, last year & 0.43 & 0.49 & 0.59 & 0.63 & 0.57 & 0.54 \\
\hline $\begin{array}{l}\text { =1 if married or cohabiting or widow or } \\
\text { divorced; }\end{array}$ & 0.70 & 0.73 & 0.72 & 0.65 & 0.65 & 0.71 \\
\hline \multicolumn{7}{|l|}{ Age at first het. intercourse } \\
\hline Aged 13-15 & 0.094 & 0.191 & 0.309 & 0.364 & 0.402 & 0.260 \\
\hline Aged 16-17 & 0.351 & 0.388 & 0.395 & 0.341 & 0.360 & 0.381 \\
\hline Aged 18-19 & 0.247 & 0.243 & 0.166 & 0.171 & 0.091 & 0.197 \\
\hline Aged 20+ & 0.308 & 0.178 & 0.130 & 0.124 & 0.146 & 0.162 \\
\hline
\end{tabular}

